\title{
Determination Of Mercury (Hg) On Water Sample In Batang Kuantan River
}

\author{
Rindi Genesa Hatika ${ }^{1}$,Indang Dewata ${ }^{2}$, Alizar $^{2}$, Purwo Subekti $^{3}$, Saiful Anwar ${ }^{3}$ \\ ${ }^{I}$ Department of Physics Education, University of Pasir Pengaraian, Rokan Hulu, Riau, Indonesia \\ E-mail: rindigenesa@gmail.com \\ ${ }^{2}$ Padang State University, Sumatra Barat, Indonesia E-mail: ___dewata@yahoo.com \\ ${ }^{3}$ Mechanical Engineering University of Pasir Pengaraian, Indonesia \\ purwos73@gmail.com
}

\begin{abstract}
:
Batang Kuantan River is a river that still has a wild gold mine along the flow. Problems arising from the gold mine is the content of the metal it produces, one of which is mercury. Mercury is used in gold mining This research was conducted to see the mercury contained in the water in the flow of Batang Kuantan river. Geochemical studies have been performed by determining the $\mathrm{pH}$ and concentration of metal mercury $(\mathrm{Hg})$ determination in water samples using Atomic Absorption Spectrophotometer (AAS). The results showed that The concentration of $\mathrm{Hg}$ on samples Al and A3 is $0.009 \mathrm{mg} / \mathrm{L}$ and $0.0078 \mathrm{mg} / \mathrm{L}$. The A2 and A3 samples found a low reading of the limit of detection. The concentration values of $\mathrm{Hg}$ samples $\mathrm{Al}$ and $\mathrm{A} 4$ are above the standards specified by PP No.82 tahun 2001 i.e $0.002 \mathrm{mg} / \mathrm{L}$.
\end{abstract}

Keywords: Mercury, River Water, Gold Mine

\section{INTRODUCTION}

Batang Kuantan River located in Sijunjung Regency is believed to have a wild gold mine which is located around the waters of the river [1]. This gold mining activity is believed to cause significant environmental damage. One of the most troubling problems for people around the location of Unlicensed Gold Mining (PETI) is heavy metals resulting from gold mining activities such as $\mathrm{Cd}$ metal derived from natural metal dissolution due to soil excavation and rock destruction. Accumulation of heavy metal $\mathrm{Cd}$ beyond the allowable limit may cause impaired renal function and cause injury to the nasal passages and skin [2]. In addition to the heavy metals produced by such PETI activities, anions such as nitrate will also harm human health [3].

One form of damage caused by gold mining by the people is mercury contamination of amalgamation process of gold processing. In the traditional gold amalgamation process by the people, mercury can be released into the environment at the stage of washing and roosting. In the washing process, waste that is generally still contain mercury is discharged directly into the body of water. This is due to the mercury is mixed / split into fine grains that are difficult to separate in the process of grinding is done 
simultaneously with the amalgamation process, so that in the process of washing mercury in the waste carried into the river [4].

Mercury is found naturally in small quantities throughout the environment. It is released by the breakdown of minerals in rocks and soil and as a byproduct of fossil fuel combustion and waste incineration. It is inhaled with the air that we breathe, absorbed through the skin, and ingested with food. The tiny amounts to which the vast majority of people are exposed do not generally cause health concerns, but exposure to excessive amounts of mercury can be toxic. The amount of mercury absorbed by an individual and its effects on his or her health depend on the type of mercury weather elemental, inorganic or organic metallic, its concentration, and the exposure time. According to the Agency for Toxic Substances and Disease Registry (ATSDR), very little metallic mercury (less than $0.01 \%$ ) is absorbed by the body, even if it is swallowed. However, if the same mercury is inhaled as a vapor, about $80 \%$ is absorbed into the bloodstream [5].

The spread of $\mathrm{Hg}$ in soil, water, or air through various channels such as solid or liquid waste disposal discharged into soil, air, and water. Surface water pollution and surface water by mercury has reached 25 percent of 2,783 samples tested by U.S. Environmental Protection Agency (EPA). Groundwater surveys have also detected mercury concentrations in some supplies of drinking water [6].

The use of mercury $(\mathrm{Hg})$ especially gold mining to separate gold from sand grains through the amalgamation process and the combustion process (alloy). $\mathrm{Hg}$-containing tailings are discharged around the settlement making it potentially contaminating soil and groundwater.

Elements of mercury or mercury are chemicals used in the processing of gold. The absorption of mercury oxide $(\mathrm{HgO})$ is mostly through the respiratory system and the amount entering the body is as great as that between the nasal or mouth sucking (about 80\%) [7:8]. Once released into the environment mercury is never broken down to a harmless form and exists in the atmosphere, soil and aquatic phase. It transform into very stable organic compounds such as methyl mercury which has a strong bioaccumulation and can be finally taken by humans [9].

Research on the mercury content produced by wild gold mining previously been implemented by Reference 10, where mercury levels in the source of clean water and drinking water, especially river water used as a source of drinking water by people around PETI Kecamatan Kurun Gunung Mas District exceeds the limit which established Permenkes 1990 and 2002 with an average mercury level of $0.003 \mathrm{mg} / \mathrm{L}$.

Badan Lingkungan Hidup Kota Palu (2011), has also conducted a study related to mercury content in ground water, river water and seawater in the city of Palu at some point in 2010 recorded $0.0036 \mathrm{ppm}$ far above the threshold of $0.0005 \mathrm{ppm}$.

Therefore, the research of Determination of mercury $(\mathrm{Hg})$ on water sample in Batang Kuantan River was conducted to find out mercury concentration in the river water sample of Kuantan river. 


\section{THE MATERIAL AND METHOD}

This research was conducted on the area around the river flow of batang kuantang in West Sumatra. Where it is believed that at this location is often done illegal gold mining activities that allow the presence of mercury $(\mathrm{Hg})$ in samples taken in the area. There are 4 specified sample locations using Global Positioning System (GPS) tool aid. The four sample sites are within a radius of 5-10 m from gold mining. Water samples was collected in 4 different sample location along the river and collected randomly in a $1000 \mathrm{ml}$ plastic container and preserved with concentrated nitric acid.

Geochemical studies have been performed by determining the $\mathrm{pH}$ and concentration of metal mercury $(\mathrm{Hg})$ determination in water samples using Atomic Absorption Spectrophotometer (AAS). In determining the $\mathrm{pH}$ of the water sample used SNI 06-6989.11.2004 test method while in determining the mercury concentration used test method of SNI 6989.78: 2011.

\section{RESULT AND DISCUSSION}

\section{pH Level}

Research on $\mathrm{pH}$ levels in water samples in all four locations around the quantan river rivers found varying $\mathrm{pH}$ levels. The $\mathrm{pH}$ levels for the water samples are shown in Table 1.

Table 1. pH Level on Sample

\begin{tabular}{llc}
\hline No & Sample Code & pH \\
\hline 1. & A1 & 6.01 \\
2. & A2 & 6.05 \\
3. & A3 & 6.09 \\
4. & A4 & 5.91 \\
\hline & Mean & 6.02 \\
\hline
\end{tabular}

The results of $\mathrm{pH}$ measurements on water samples in quantan rod rivers at the four sample sites found that at the A1-A3 sample sites are still within the standard set by Ref [11] i.e 6-9. While the A4 sample location is below the standard set by PP No. 82 tahun 2001 i.e 6-9. On average, the overall $\mathrm{pH}$ level in batang kuantan river is still within the established standard set by Ref [11] i.e 6-9. The $\mathrm{pH}$ value of water sample on Batang Kuantang river on average 6.02 .

The $\mathrm{pH}$ value is influenced by several parameters, including biological activity, temperature, oxygen content and ions. From the biological activity produced $\mathrm{CO} 2$ gas which is the result of respiration. This gas will form buffer ions or buffers to keep the $\mathrm{pH}$ range in the waters stable [12]. The lower the $\mathrm{pH}$ value, the higher soil acidity. 
The results of this study found that all water samples collected were slightly acidic. Reference [13] states that the more acidic the $\mathrm{pH}$ of a sample is then enhance the mobility of mercury in the environment likewise its adsorption to clay and mineral oxides of iron, aluminum and silicon.

\section{Mercury (Hg)}

Testing of mercury ( $\mathrm{Hg}$ ) concentration has been performed using Atomic Absorption Spectrophotometer (AAS). The $\mathrm{Hg}$ concentration in the water samples in the four sample locations is shown in Table 2.

\begin{tabular}{|c|c|c|}
\hline No & Sample Code & Hg $(\mathrm{mg} / \mathrm{L})$ \\
\hline 1. & A1 & 0.009 \\
\hline 2. & $\mathrm{~A} 2$ & $<0.0003 *$ \\
\hline 3. & A3 & $<0.0003^{*}$ \\
\hline 4. & A4 & 0.0078 \\
\hline
\end{tabular}

* LoD= Limit of Detection

On Sample location A1 found that the concentration $\mathrm{Hg}$ value is $0.009 \mathrm{mg} / \mathrm{L}$. This value is above the standard set by PP No.82 tahun 2001 i.e $0.002 \mathrm{mg} / \mathrm{L}$. On Sample location A2 and A3 found that the concentration $\mathrm{Hg}$ value is $<0.0003 \mathrm{mg} / \mathrm{L}$. This value is below the standards set by PP No.82 tahun 2001 i.e $0.002 \mathrm{mg} / \mathrm{L}$. On Sample location A4 found that the concentration $\mathrm{Hg}$ value is $0.0078 \mathrm{mg} / \mathrm{L}$. This value is above the standard set by PP No.82 tahun 2001 i.e $0.002 \mathrm{mg} / \mathrm{L}$. Location A1 and A4 is the closest location to the gold mine in the Batang Kuantan river, allowing it to have a higher $\mathrm{Hg}$ concentration in comparison with the more remote A2 and A3 locations. The gold mining around the Batang Kuantan river uses amalgamation processing.

In the traditional gold amalgamation process by the people, mercury can be released into the environment at the stage of washing and roosting. In the washing process, waste that is generally still contain mercury is discharged directly into the body of water. This is due to the mercury is mixed / split into fine grains that are difficult to separate in the process of grinding is done simultaneously with the amalgamation process, so that in the process of washing mercury in the waste carried into the river [4].

\section{Comparism of Mercury (Hg) Concentration with WHO limit}

The concentration of mercury $(\mathrm{Hg})$ in the whole sample of batang kuantan river can then be compared with WHO limit as it is shown in Figure 1 below. The concentration of mercury in water sampel A1 and A4 was high compared to $0.001 \mathrm{mg} / \mathrm{L}$ limit recommended by WHO. This could be detrimental to the communities around the river who depend solely on the water from the river for their livelihood like for drinking, washing, bathing etc. EPA report has revealed that elevated mercury levels has been linked to learning disabilities and developmental delays in children and to heart nervous system and kidney damage in adults. 
Other than that the $\mathrm{pH}$ in the water samples in $\mathrm{A} 1$ and $\mathrm{A} 4$ is the most acidic compared to the water samples in A2 and A3 so as to support that the A1 and A4 samples are of higher $\mathrm{Hg}$ concentration. Reference [13] suggest that the more acidic the $\mathrm{pH}$ of a sample is then enhance the mobility of mercury in the environment likewise its adsorption to clay and mineral oxides of iron, aluminum and silicon.

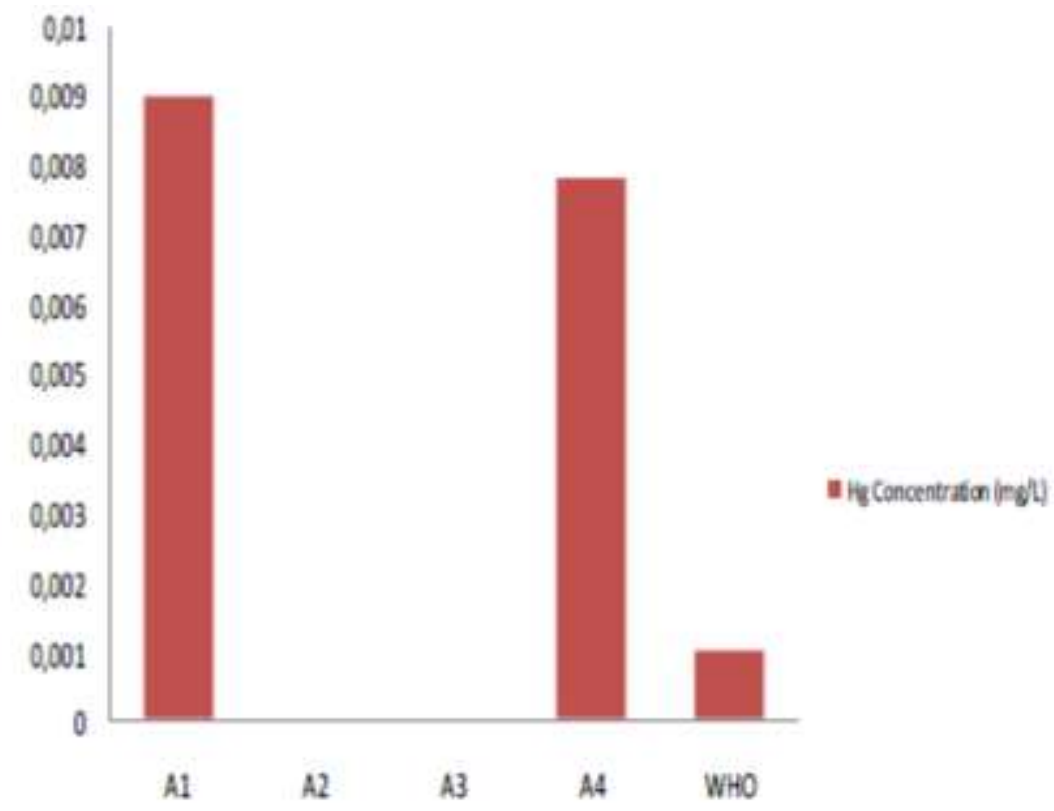

Pig. 1. Comparism of Mercury (Hg) Concentration with WHO limit

The presence of $\mathrm{Hg}$ in the river may occur due to gold / mining processing activities ie amalgamation and bleaching process, where $\mathrm{Hg}$ can enter the ground water / surface water through seepage and rain water that drops along with $\mathrm{Hg}$ in amosfir [14].

\section{CONCLUSIONS}

The concentration of $\mathrm{Hg}$ on samples A1 and A4 is $0.009 \mathrm{mg} / \mathrm{L}$ and 0.0078 $\mathrm{mg} / \mathrm{L}$. The A2 and A3 samples found a low reading of the limit of detection. The concentration values of $\mathrm{Hg}$ samples $\mathrm{A} 1$ and $\mathrm{A} 4$ are above the standards specified by PP No.82 tahun 2001 i.e $0.002 \mathrm{mg} / \mathrm{L}$.

\section{ACKNOWLEDGMENT}

We would like to thank RistekDikti for support this research.

\section{REFERENCES}

[1] Dinas Pertambangan dan Energi Kab.Sijunjung dan BKPM Provinsi Sumatera Barat. 2014. Potensi Pertambangan. Diakses di http://sijunjungkab.go.id/brt/potensipertambangan/.

[2] Darmono. 2006. Lingkungan Hidup Dan Pencemaran, Hubungannya Dengan Toksikologi Senyawa Logam. UI Press, Jakarta. 
[3] Dewi, R. P. 2009. Analisis Kontribusi Logam Berat Hg, Cd), Nitrat dan Sulfat dari limbah tambang emas kepada badan air Sungai Petapahan Kuansing. Skripsi. Jurusan Kimia. FMIPA. Universitas Riau, Pekanbaru.

[4] Widhiyatna, Denni., Pendataan Penyebaran Merkuri akibat Usaha Pertambangan Emas Di Daerah Tasikmalaya, Propinsi Jawa Barat, Kolokium Hasil Lapanga. DIM. 2005.

[5] Agency for Toxic Substances and Disease Registry Atlanta (ATSDR). 2011. Toxicological profile for mercury. Retrieved March 15, 2017, from www.atsdr.cdc.gov/toxprofiles/tp.asp?id=115\&tid=24.

[6] Putranto, Thomas, (2011), Pencemaran Logam Berat Merkuri (Hg) Pada Air Tanah , Teknik - Vol. 32 No. 1 Tahun 2011, ISSN 0852-1697, Universitas Diponegoro : Jurusan Teknik Geologi, Fakultas Teknik.

[7] WHO Regional Officer For Europe, (2000), Air Quality Guidelines, Second Edition, Copenhagen, Denmark.

[8] Rianto, Sugeng, (2010), Analisis Faktor - Faktor Yang Berhubungan Dengan Keracunan Merkuri Pada Penambang Emas Tradisional di Desa Jendi Kecamatan Selogiri Kabupaten Wonogiri, Semarang : Program Studi Magister Kesehatan Lingkungan, Program Pasca Sarjana, Universitas Diponegoro.

[9] Basel Convention (2010). Technical Guidelines for the Environmentally Sound Management of Wastes Consisting of, Containing or Contaminated with Mercury 5th Draft. Retrieved June. 20, 2017 from www.basel.int/Portals/4/Basel\%20Convention/docstech matters/merc ury/guidelines/UNEP-CHW-10-6-Add_2_rev_1.pdf "PDCA12-70 data sheet," Opto Speed SA, Mezzovico, Switzerland.

[10] Lestarisa, Trilianty, (2010), Faktor-Faktor Yang Berhubungan Dengan Keracunan Merkuri (Hg) Pada Penambang Emas Tanpa Ijin (PETI) di Kecamatan Kurun Kabupaten Gunung Mas, Semarang : Universitas Diponogoro.

[11] Peraturan Pemerintah No.82 Tahun 2001. Pengelolaan Kualitas Air dan Pengendalian Pencemaran Air.

[12] Pescod NB. 1973. Investigation of Inland Water and Estuaries. New York:ReinholdPubilshing Corporation.

[13] Kim C, Rytuba JJ, Brown JGE (2004). EXAFS study of mercury (II) sorption to Feand Al-(hydroxides) I. Effect of $\mathrm{pH}$. Journal of Colloid and Interface Science, 271, pp. $1-15$.

[14] WHO, (2008), Guidance For Identifying Populations At Risk From Mercury Exposure, August 2008, Geneva, Switzerland : Department of Food Safety, Zoonoses and Foodborne Diseases Cluster on Health Security and Environment, 20 Avenue Appia 1211. 